\title{
Multidimensional analysis of Latin American indigenous peoples against Covid-19
}

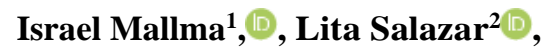

\begin{abstract}
Abstrac
Background: and objectives: Covid-19 is a global pandemic that requires a culturally integrated response in all Latin American government systems. In this study, we investigate the multidimensional associations of actions in Latin American indigenous peoples against Covid-19

Methods: We performed a data mining analysis of scientific literature records from 19 academic journals, using the topics Covid-19, mortality, indigenous peoples, and future measures, rights and actions. The literature is analyzed in a multidimensional way, either isolated or combined. It uses switchable statistical methods, the R Studio, worddj, Gephi, and Iramuteq for both textual and multidimensional analysis.

Results and Conclusions: In this analysis, the literature is classified into 4 linked groups which are the indigenous people, the rights of territorial protection, the indigenous health culture, the Covid-19 pandemic with its protection efforts. Taking the indigenous peoples as an axis, we observe that the covid pandemic and the protection of their territories do not have the same force in the current context, the indigenous people are more linked to the protection of their territory. Indigenous peoples have a link of cultural strength in traditional health independent of Covid treatment. It should be noted that government agencies are taking measures regarding the covid pandemic with an effort not marked within the health culture of indigenous peoples.
\end{abstract}

Keywords: Indigenous peoples, Latin American, Covid 19, indigenous rights, health culture, government agencies.

\section{Introduction}

In September 2019, the World Health Organization mentioned preparing for a pandemic caused by a lethal pathogen and the rapidly spreading covid-19.[1] It is also detailed that $95 \%$ of the indigenous population in Latin American countries has been reduced in the last 300 years, due to diseases spread by the colonizers, this phenomenon is worrying in indigenous communities.[2]. Statistically, indigenous peoples constitute $6 \%$ of the entire world population [3].

$80 \%$ of this population is concentrated in Bolivia, Guatemala, Mexico and Peru. Historically, rural indigenous communities have obstacles to access health services due to profound discrimination based on ethnic origin, poverty, and language. Regarding public health, indigenous peoples are one of the sectors with the least access to basic services: $48 \%$ without drainage, $30 \%$ without drinking water, and $75 \%$ without access to health services [4].

There are collective references in countries such as the United States, in which immigrants are accused of being responsible for diseases in different historical moments, this association is a cultural and political construct in force today.[5]

Indigenous peoples are considered to be historically colonized, there is continuous negligence on the part of the rulers, and changes in

\footnotetext{
${ }^{1}$ Doctor in Mining Safety and Control, Master's in mining management, Faculty of Mining Engineering, Graduate School of the National University of the Center of Peru; israel_minner@hotmail.com

${ }^{2}$ Doctor in Educational Sciences, Master's in educational management, Faculty of Education, graduate school of the National University of the Center of Peru; litapierina@hotmail.com
} 
diets and ways of life associated with an increasingly frequent interaction with outsiders.[6]. The spread of covid-19 does not distinguish borders, but paradoxically the states of a joke in isolating itself, as the main resource to safeguard the lives of its citizens [5].

This situation worsens even more, when there is confrontation, destruction, erosion of basic services and displacement of people who live in the middle of armed conflicts, and who must face the threat of COVID-19.

Despite all this, according to [7] We continue to have conflicts in the world, the UN mentions in making a ceasefire, which allows humanitarian aid actions to cope with the coronavirus pandemic. Many people depend on this humanitarian aid to survive [8].

Said inequalities mentioned among indigenous peoples constitute a factor of vulnerability that generally affect their population, especially young women and children [1].

\section{Materials and methods}

We use computable and multiple correspondence statistical methods for data and analysis of the Covid-19 scientific literature and indigenous peoples. The specific approach to mining and data analysis was focused on three specific topics using the Covid-19 topics, mortality, indigenous peoples and applied measures, indigenous rights and future actions. Then we analyze the data records with $\mathrm{R}$ Studio, worddj, Gephi and Iramuteq. for both textual and multidimensional analysis.

The analysis of different data sets would produce even more figures, it is based on the data of the 19 academic journals. Among them: Aba Antropología, Apuntes ECP de Conflictes i Pau, Inter-American Development Bank, Economic Commission for Latin America and the Caribbean, Department of Economic and social affairs, Diabetes \& metabolic syndrome, Team of rights and communities, Geopolitics, National Institute of Indigenous Peoples, International Committee of the Red Cross, International Journal for Equity in Health, Indigenous Navigator, United Nations Office for the Coordination of Humanitarian Affairs, United Nations, Pan American Health Organization, Oxfam International, Self-Thinking, Python Cookbook, SIT Collections.
This methodology allows contextually, to analyze the current crisis of the COVID-19 pandemic in which it can deepen inequalities in rights and social and economic exclusion, and the cultural difference in the health application suffered by indigenous peoples [9].

It could be mentioned that, in addition, a comparison could be made at a later stage. This analysis is a deepening of the investigations initiated and raised by[10]

\section{Data analysis in R studio, worddj, Gephi and Iramuteq}

Analysis in R Studio, wordj, Gephi, and Iramuteq helps you discover more from your qualitative and mixed methods data. once the text is processed:

a) Every sentence and word in every document is analyzed from beginning to end.

b) This process includes text segmentation, stemming, and the selection of key terms.

c) Subsequently, they are analyzed with cooccurrence tools that allow us to measure, explore and map various types of relationships between key terms, either in pairs or in groups.

d) From there we move on to a thematic analysis dealing mainly with finding keyword patterns within context units.

e) To finalize a comparative analysis, they allow us to analyze and map similarities and differences between subsets of the study, each of which has a specific lexical profile resulting from the key terms found in it.

\section{Textual analysis}

The literary analysis shows us a classification into four groups, the first one referring to the community or indigenous people, the second referring to the rights and strategies of the government to protect their territories, the third group includes traditional culture. and the health system that exists, the fourth group refers to the Covid-19 pandemic, protection and existing efforts to mitigate and protect communities, as shown in the dendrogram of the Fig. 1.

The correlation of the logarithm of word occurrence (x-axis) with the logarithm of frequency of use, which shows us a trend analysis in the figure, fulfilling the law of called Zipf's law as seen in Fig. 1. 
Zipf's law expresses the following: $P_{n} \sim \frac{1}{n^{a}}$

Where:

$>$ Pn: represents the frequency of a word in the nth position (words are ordered from highest to lowest frequency)

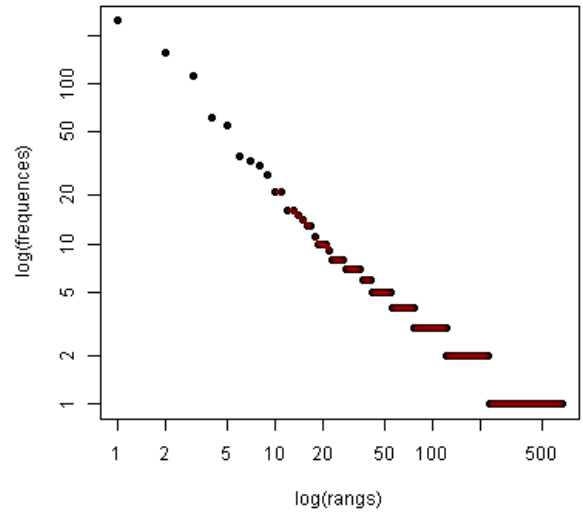

(A)

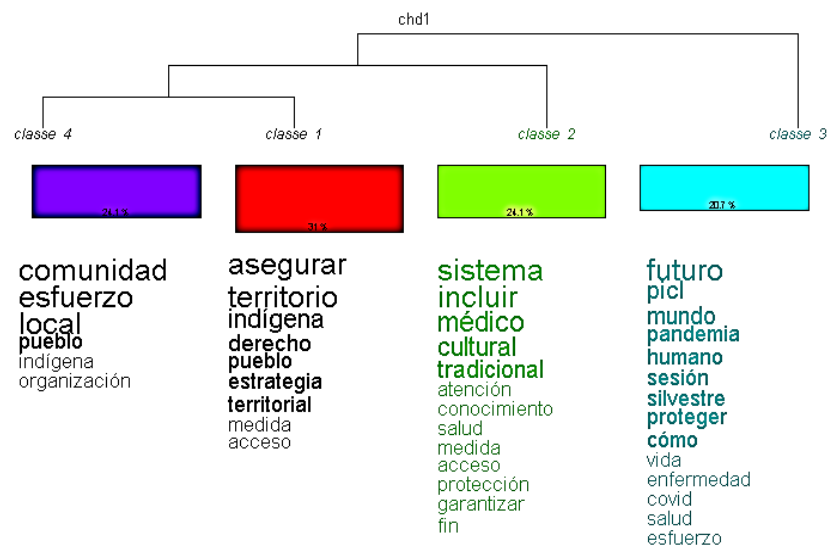

(B)
Fig. 1 (A) Correlation analysis of $\log$ (rangs) and $\log$ (frequencies), (B) dendogram of textual analysis

\subsection{Co-occurrence analysis}

Using the statistical methodology of the embedding of stochastic neighbors distributed in $\mathrm{t}$ a: close to 1

This explains that the second element of a series will be repeated approximately with a frequency of $1 / 2$ of that of the first

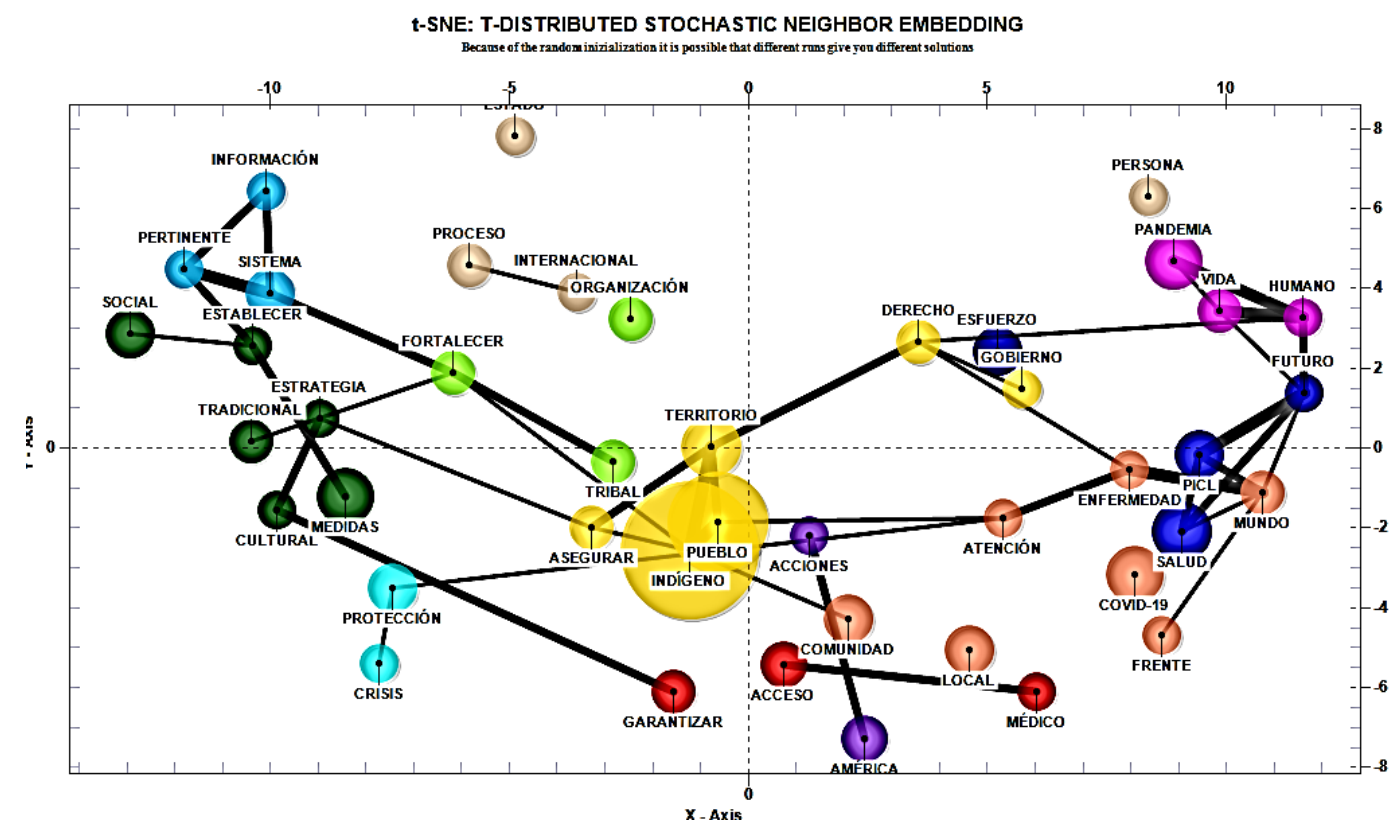

Fig. 2 (A) Correlation analysis of $\log$ (rangs) and $\log$ (frequencies), (B) dendogram of textual analysis
How can we observe indigenous peoples, they have strong links with respect to their own health culture. Indigenous peoples are finding their own solutions to respond to the health crisis, based on their traditional knowledge and practices[11]. The most excluded people in the world will be seriously compromised [12]. Regardless of their political or
(t-SNE) to visualize multidimensional data, in a two-dimensional map. We get the following: ideological differences, they must agree on cooperation plans or, at least, on a more fruitful dialogue than the one held before the start of the pandemic [5].

The response of indigenous peoples regarding the pandemic, they have independent links regarding the culture they have, they consider in the 
first instance the right to territorial protection. In the first instance, there is no solid link between governments in relation to indigenous peoples to face the crisis of the covid-19 pandemic.

Formulating inclusive responses to covid-19 with indigenous peoples: a rights-based approach and strengthening protection of land tenure, employment and support for traditional livelihoods, community participation indigenous peoples in controlling the transmission of COVID-19[13].

Regarding the participation of the state in the face of the pandemic, it can be observed that the links are very independent, not correlational with the indigenous people pandemic context

In response, many communities have barricaded themselves and isolated themselves from outsiders, organizing to seek necessary supplies outside the community [2]. The case of Brazil, for example, that no measures were implemented, but that groups such as COICA, which represents Amazonian indigenous peoples in 9 countries, demanded the restriction of access [2].

It is necessary to guarantee the participation of indigenous peoples through their representative organizations, including indigenous women and youth organizations, with national, regional and local action plans [1].

This can also be observed in the promotion of distance education and adequate social services. PRINCIPAL COMPONENT ANALYSIS

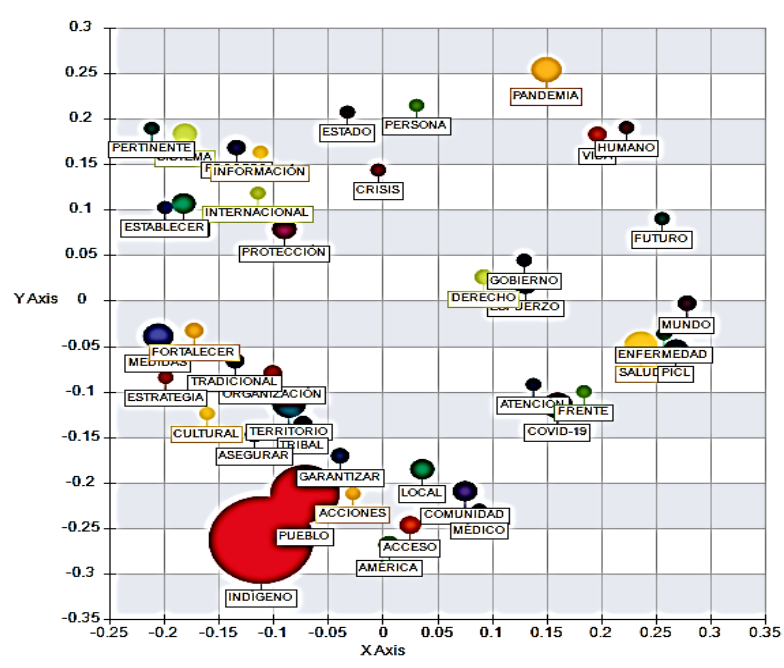

Fig. 3 (A) Factor analysis represented in two dimensions (B) Sectorized factor analysis in quadrant.

It can be seen that governments are within a quadrant independent from that of indigenous peoples. The Region of the Americas is characterized by its multiethnic and multicultural wealth. However, indigenous peoples, Afro-
Although governments have tried to ensure the continuity of education by promoting the use of distance learning methods, many indigenous peoples are excluded due to lack of technical equipment and appropriate Internet connectivity [13]. The impact of the lack of historical funds and the lack of adequate social services on indigenous communities becomes more evident in the face of a pandemic like this one [14].

In the analysis of the main factors, it can also be detailed that the indigenous people have more links with territorial defense and the measures regarding them, we can also observe that the links regarding the pandemic have a better response worldwide and a less response in South America, due to the fact that governments are not included in objective solutions, even worse linked to the cultural issue. Regarding solutions to the covid 19 pandemic.

To protect the community from external contagion of the virus, it details to create a fence or protection cordon in coordination with local authorities (local government, police, etc.) and indigenous people. Create an emergency committee to think and coordinate community actions. Controlling the entry of suppliers or intermediaries for the purchase and sale of food and closely coordinating with public sector authorities in the delivery of food, vouchers, health products for the prevention of the virus, etc.[15].

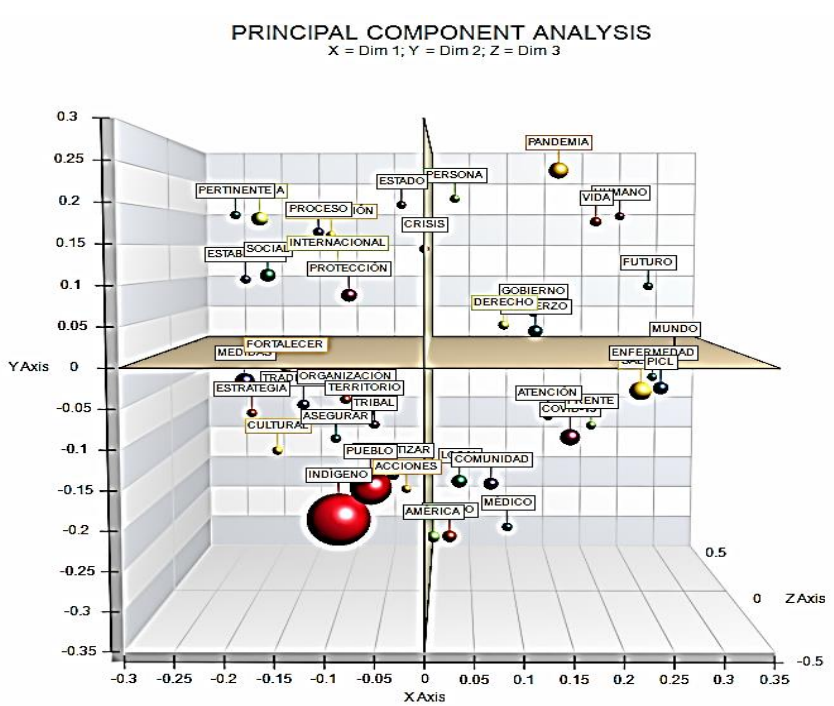

descendants, and other ethnic groups often face discrimination and exclusion, leading to inequities in health. The impact of COVID-19 could be greater in certain population groups, such as indigenous peoples and the Afro-descendant population [16]. 
There are pre-existing detected inequalities, such as employment and working conditions, social protection, access to education, access to health care, food and land security[13]. According to the Inter-American Commission on Human Rights (IACHR), indigenous peoples are one of the human groups most at risk from the pandemic [17].

So much so that indigenous peoples also take measures independent of the government. In this sense, the peculiarities of indigenous peoples in voluntary isolation that do not maintain sustained contact with the majority population that is not indigenous stand out, for example [16].

Despite the existence of international organizations, they also do not escape being independent from the context of indigenous peoples, without detailing the health context in which indigenous peoples find themselves.

According to him [15]. It is hand washing and distancing between people, it is the best way to protect yourself from this disease. But if people develop a fever, cough, and shortness of breath, they should seek immediate medical attention, noting that older people with conditions such as high blood pressure, heart problems, or diabetes are more likely to become seriously ill. Support for communities and their authorities in decision-making and the implementation of prevention actions includes an economic and human cost.

These measures are independent of the context in which indigenous peoples develop. The solution must not, however, be the militarization of the borders. Many indigenous territories transcend border limits and move daily for their basic subsistence activities.[17].

How can we observe such measures by not keeping congruence with the context of covid-19 and indigenous peoples, who have a greater link with the land in which they develop productively.

At present, the production and reproduction of inequalities that affect indigenous peoples is based on the persistence of neocolonial political and economic power structures, which favor the dispossession of communities within the framework of the extractivist model in force in all the countries of the the region[17].

In sum, it should be noted that the social organization of indigenous peoples is based on collective structures, both at the family and community level, which implies different realities for the measures of isolation and social distancing. The worldview and traditional knowledge about health constitute the immediate resources of indigenous peoples. Respecting them is essential to establish effective interaction, the linguistic diversity of indigenous peoples requires interpreters to effectively communicate response measures to the crisis.[18].

If these factors are linked by thematic nuclei on the plane, it shows us four defined groups, although not included in some aspects, but distant with respect to indigenous peoples. We can detail, for example, that the issue of the government's response regarding health has more distant links than the central nucleus.

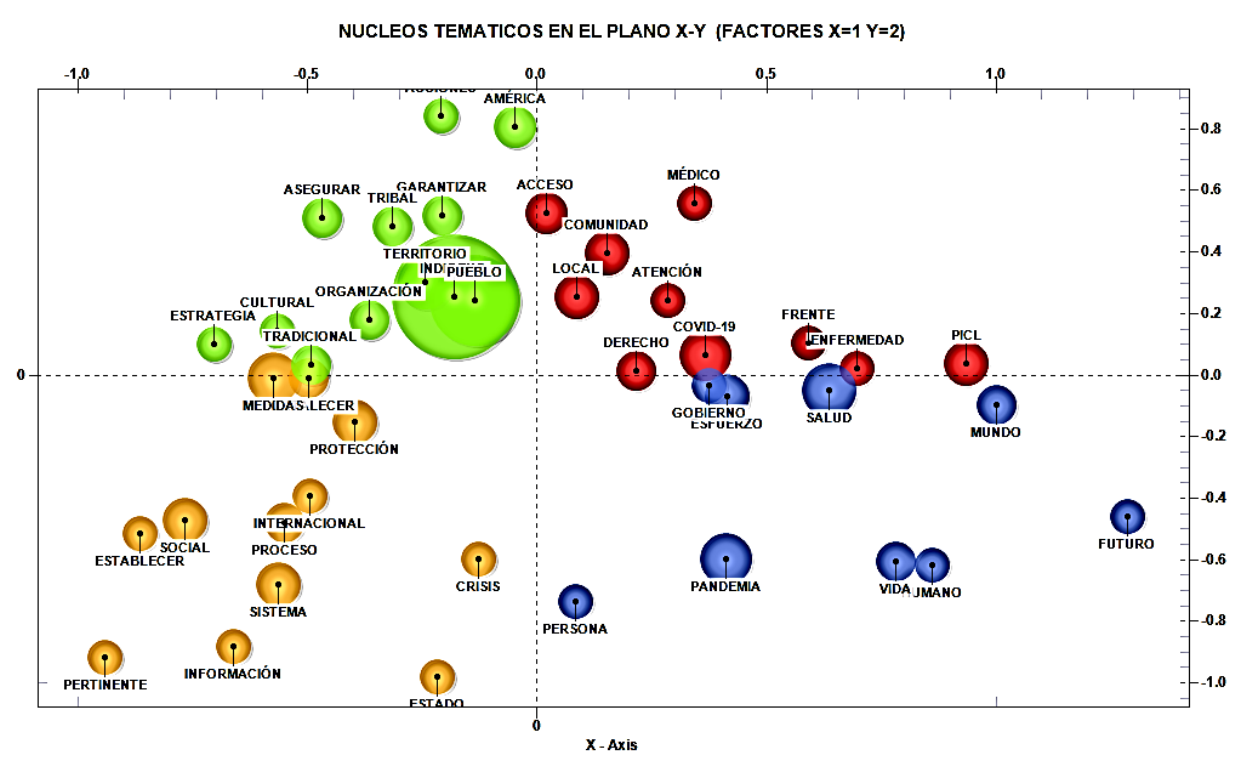

Fig. 4 Thematic nuclei of textual analysis. 
At a global level, if we compare the responses of covid-19, we can detail which America has distant links in response regarding the care of the pandemic, globally there is a better response on the issue of dealing with covid-19, but culturally to world level there is a distance with respect to the care of its indigenous peoples, it should be noted that the largest population of indigenous peoples is in Latin America.

In a comparative analysis of the indigenous people regarding alcohol in Latin America, we can detail that there are distanced links, because indigenous peoples are focused on protecting their territories and their actions are aimed at it, on the other hand it can be observed that the pandemic does not It is adequately cared for and the measures are linked more to the protection of their territories than to strengthening actions to deal with the covid.

This is because indigenous peoples are perhaps almost three times more likely to live in extreme poverty than non-indigenous peoples. They represent almost $19 \%$ of those living in extreme poverty, regardless of the region where they live, be it in rural or urban areas and even across international borders[3]

COVID-19/INDIGENO

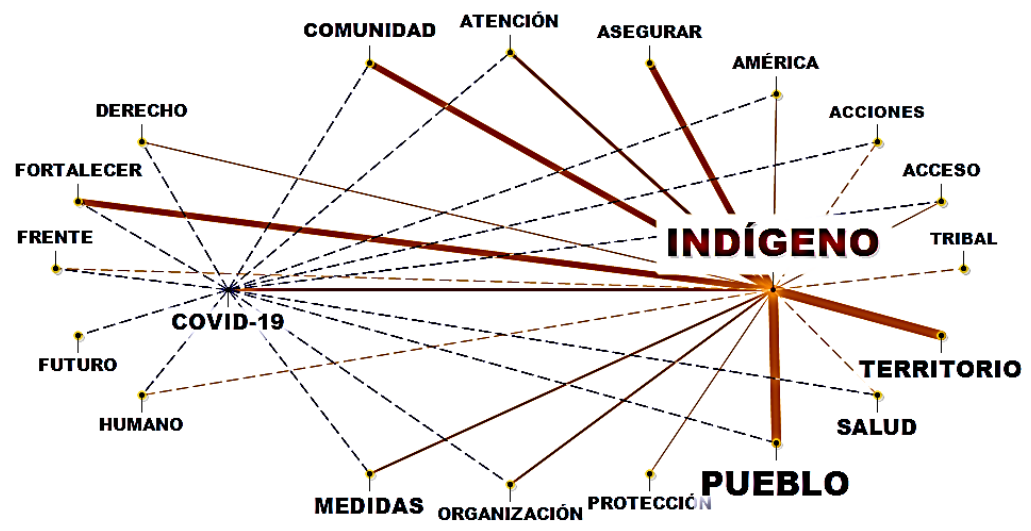

Fig. 5 Analysis of associations between Covid-19 and the Indigenous People.

These differences regarding priorities, the pandemic, and government measures resulted in the highest number of deaths in the Americas region. Some Latin American countries are among the 20 nations that, globally, register the highest number of infected and deceased by COVID-19 (Brazil, Peru, Colombia, Mexico, Argentina and Chile); in addition to being on the list of the 20 countries with the highest number of cases per million inhabitants (Panama, Chile, Peru, Brazil and Colombia) [1].

In the Fig. 6 Analysis of associations between Covid-19 and the Indigenous People. In graphic (A) we can detail, that the textual association of covid19 is far from the cultural issue and the respective attention, it can also be detailed in graphic (B) that the indigenous people have very close associations with respect to the right of their territories, and they are more distanced with respect to the actions and attention of the pandemic caused by the covid-19.

According to the Peruvian newspaper [18] in all aspects there must be a respect for the worldview and traditional knowledge about health, including traditional doctors, methods, medicine and beliefs.
In the Fig. 7 (A) he principle of the protection of the right to their lands of the indigenous peoples their actions are more linked, than in the matter of disease and cultural care, and even more it can be observed that indigenous populations are more associated in this field than the state itself. (B) How we can observe the measures regarding the contractual issue of the pandemic, they are far away in South American countries, and I can also observe it internationally. It would be pertinent to focus priorities on the issue of guaranteeing and strengthening actions in the context of the pandemic.

In addition to poverty and underlying health status, many indigenous peoples live in isolated or remote communities, where health care services are difficult to reach and have limited or simply nonexistent capacity.[3] The concern about diseases is very recurrent as it is a phenomenon that threatens the subsistence of these communities. However, the measures of confinement become difficult to comply with since subsistence has time horizons that do not exceed one day [2]. 


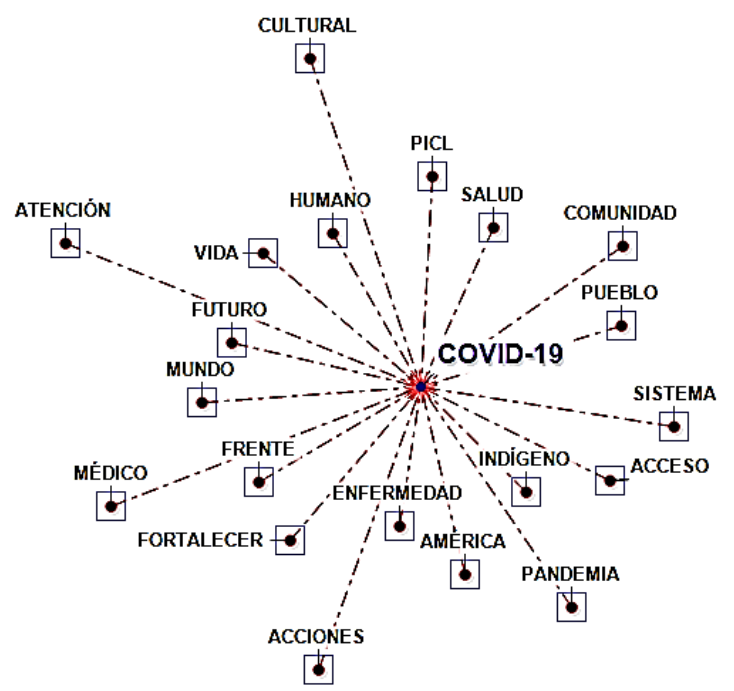

(A)

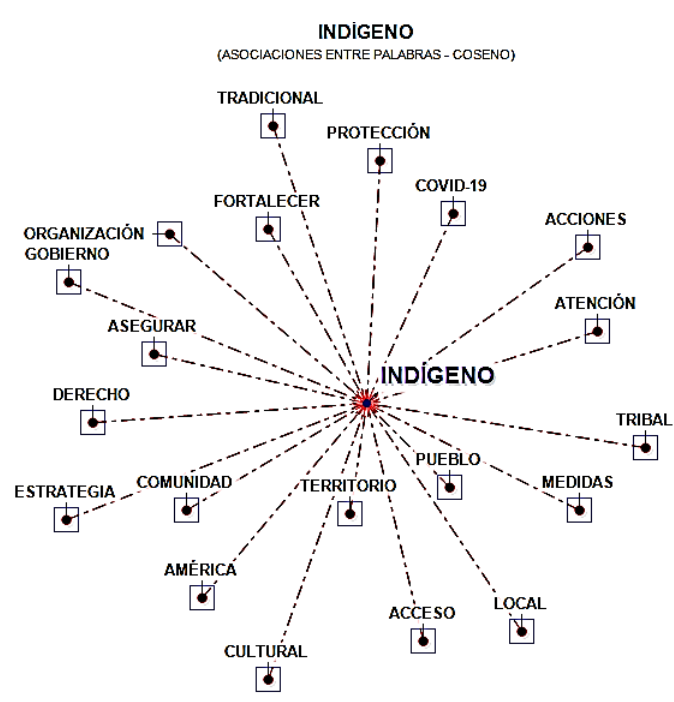

(B)

Fig. 6 Analysis of associations between Covid-19 and the Indigenous People.

The indigenous peoples and local communities are particularly vulnerable to threats to their health, including COVID-19, due to inadequate access to medical care and underlying health conditions, and

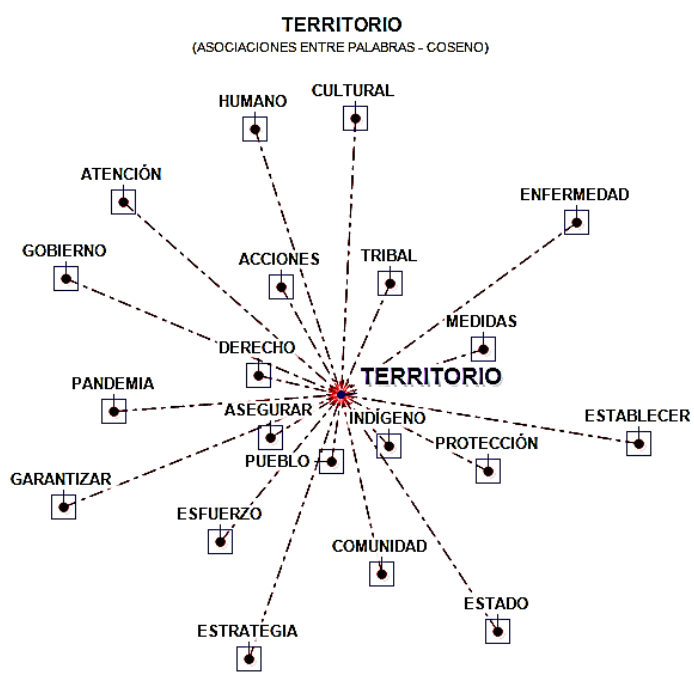

(A) which are often a consequence of historical colonization, continued negligence on the part of the state, and changes in diets [6]

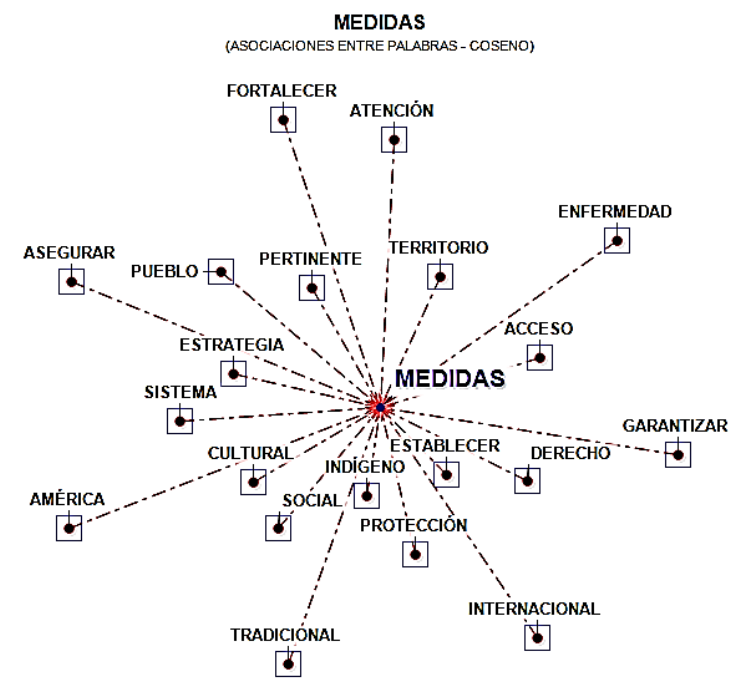

(B)

Fig. 7 Analysis of associations between Covid-19 and the Indigenous People.

\section{Results and discussions}

Regarding the similarities, we can detail that the covid-19 is associated with the human factor, in the future when facing and strengthening these measures, with respect to the indigenous people in Latin America they are focused on strengthening and ensuring the protection of their lands as organizations and measures focused on her. In summary It could be said that priorities have not changed in the context of the pandemic.
Despite some inconsistencies in indigenous peoples' objectives regarding COVID, the problems still persist. [1] details that there is invisible and collective resistance towards indigenous peoples of Latin America, mentions that in addition to precariousness, there are restrictive sanitary measures, which affect indigenous producers, as well as their access to markets. 


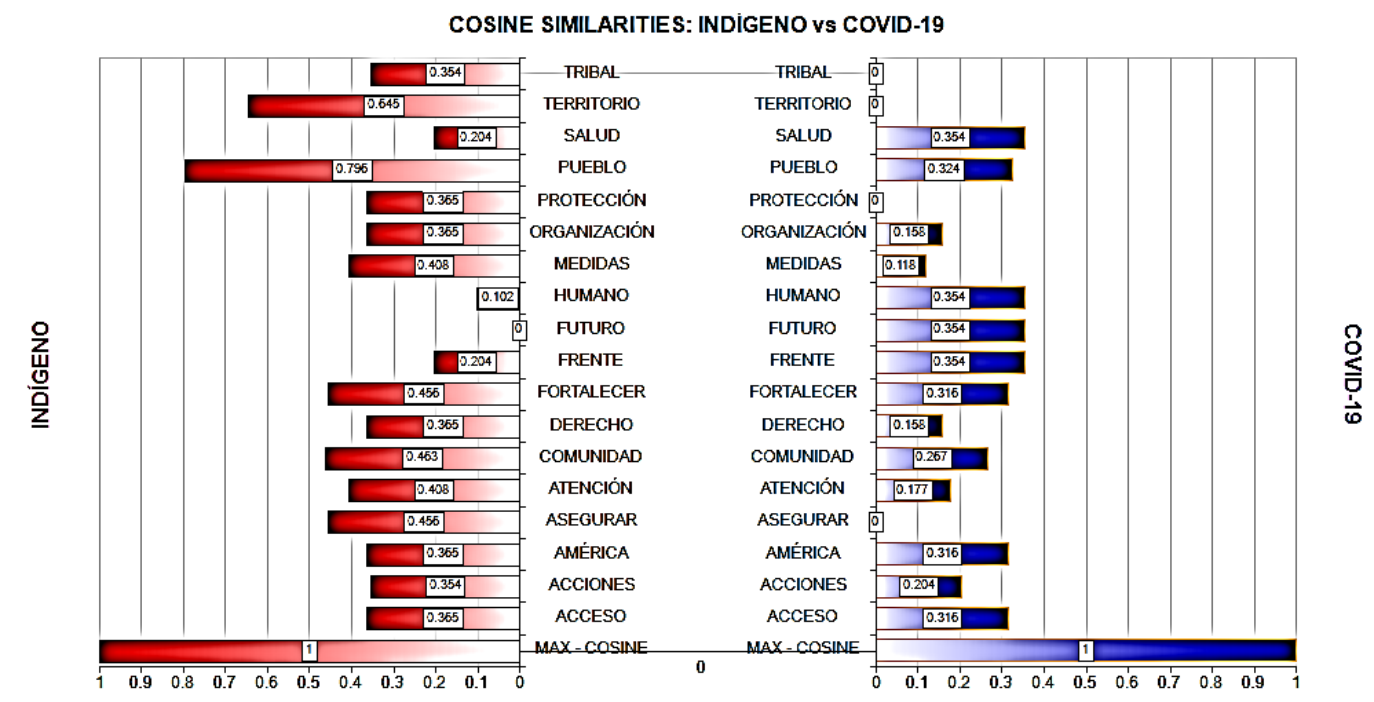

Fig. 8 Analysis of associations between Covid-19 and the Indigenous People.

State participation is important in the context of the pandemic for indigenous peoples, the responses of a cultural nature applied by the State of Mexico are highlighted:

Where measures are taken in relation to indigenous and Afro-Mexican communities, such that they will contribute to the health authority to face the pandemic, guaranteeing a safe transfer free of infections. In cases of the death of indigenous or Afro-Mexican people, measures of spiritual respect for the culture of the person will be applied. In addition to promoting measures for the prevention of discrimination, to avoid stigmatization, your family, friends or contacts[19].

This presence of the government must also be embedded in the economic issue of indigenous peoples, since the traditional livelihood of indigenous peoples has been seriously affected, because they cannot go out to collect products. [13]. In addition, these peoples do not have the ability to save and their subsistence method requires daily work.[2]. Imposing strict quarantines that to a greater extent affected indigenous peoples, leave them without medical attention or financial assistance. For example, in the country of Argentina that implemented a very strict quarantine, a percentage of the population was unable to work.[2]

It should be noted that the unpaid workload and care work increased, both in its individual and collective dimensions, taking into account not only household activities, but also those aimed at ensuring survival and community well-being [1].

It can also be observed in health care, in indigenous peoples, it is very scarce because the mechanisms and processes focused on this issue are not adequate. This can be made worse still by the deepening confluence between governments and international pharmaceutical companies [5], which prevent the arrival of these products in a timely and effective manner to the inhabitants of the indigenous peoples of Latin America.

As I have not been able to detail in almost all the analyzes, culture is directly linked to indigenous peoples. Therefore, the impulse from conspiracy and xenophobic theories against the presence of immigrants to racialization and anti-Semitic ideologies in favor of the supremacy of the race and ultra-nationalism should be avoided.[5]. Actions such as, for example, prohibiting foreign citizens from entering the country where the police organize raids to locate them and force them into confinement, regardless of their travel records [5].

There is a latent threat from some countries and their historical domination over colonial, underdeveloped or Third World nations, in terms of racialization and biopolitics over the "others" [5]. All of this is linked to the "geopolitics of fear". An example occurred in 2003 when, as a result of the attack on Iraq, terrorist attacks with smallpox and other pathogens took place in major American cities [5].

Contemporary geopolitics is being rebuilt from a multipolarity where economic resources continue to have a fundamental weight, but where scientific and technological knowledge in health is more important [5]. As the historian Raoul Girardet stated, the myth of the plot and the conspiracy continues to have enormous force to this day, in the 
field of human relations and beyond its countless narrative versions.[5]

Regarding the analysis of similarities below, we can detail the indigenous peoples are more Associated, to the right of their territories, but that to a great extent should also be Associated with the cultural, social issue and efforts to improve health,
Latin America despite of having the largest number of indigenous population, in their governments the States are not focused on it, the pandemic is being reviewed by the governments in an isolated way with independent responses to the context in which the indigenous people developed and that they do not include optimal measurements.

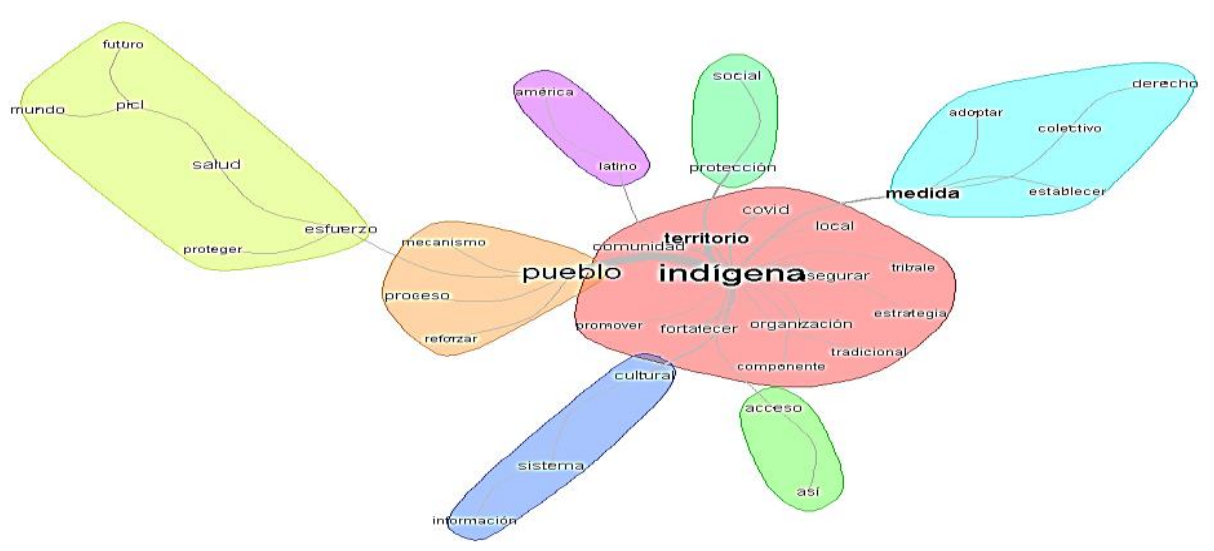

Fig. 9 Analysis of associations between Covid-19 and the Indigenous People.

In Latin America we can detail that indigenous peoples need strategies that include the cultural issue in the fight against the covid 19 pandemic, there is a link that is far from culturally inclusive measures, in Latin America. It should be noted that the information system for this process of pandemic fight is important as well as the aspect of social protection and the necessary accesses for timely assistance. In this sense, some references regarding this are detailed.

One of the most widespread measures (10 countries) is the production of audiovisual material in indigenous languages to ensure the access of these peoples to information on the disease[1] It is essential to plan differentiated communication strategies with immediate reach for populations with limited access to information and communication technologies (ICT), as well as the mass media [18].

It mentions that health communication programs are sufficient and, specifically, guaranteeing the right to information of indigenous peoples in the context of COVID-19 [20]. A translation and broadcast with cultural and linguistic relevance related to the epidemic should be disseminated and transmitted with cultural and linguistic relevance [19].

It is necessary to strengthen communication strategies on COVID-19 together with and for indigenous peoples, giving priority not only to biomedical content, but also to knowledge and practices of self-care and prevention that are part of the cultural heritage of indigenous peoples. indigenous peoples and their traditional health systems

Regarding social programs, educational programs must be relevant for rural contexts, especially for communities that, due to lack of internet connectivity, cannot carry out educational activities online.[19].

A necessary reflection of indigenous peoples in the face of covid-19 is to provide an opportunity to build new models that are more people-centered, supportive and sustainable and establish new political and social pacts. And avoiddeaths among these people, according to [21] it is due to the lack of urgent measures to prevent contagion. And evitar the rivalry between states for the coronavirus 
vaccine in a race against time, as that does more than increase existing tensions from the trade war [5].

\section{Conclusions.}

The insistence of 4 linked groups is detailed, which are: the indigenous people, the rights of territorial protection, the indigenous health culture, the covid-19 pandemic with its protection efforts, with significant importance in that order mentioned.

Indigenous peoples have a close to strong link with the defense of territorial protection rights in the current context, the links regarding culture and the issue of the pandemic show an independence, which details that the actions for both aspects are different

The efforts to protect the states or governments influencing indigenous peoples, in the face of COVID-19, have distant responses regarding the cultural, it should be noted that the global response to the treatment of this pandemic is closer to that of Latin American governments.

The relevant information system in indigenous peoples according to their culture is very distant, it is observed that there is no link regarding the policies of the governments regarding this.

\section{Author contributions}

In the present we can detail that the benefits of multidimensional textual analysis, in the analysis of scientific data mining it is important to categorize and determine influential aspects within said articles. For this, it is important to use qualitative and quantitative methodologies, with the help of statistical processes and simulations in computer programs, an interpretation and a systemic contribution of research is given on the multidimensional analysis of indigenous peoples with respect to the COVID-19 pandemic. 19. In which strong links are determined regarding the cultural issue, independence of government policies, regarding the pandemic, and relevant communication for indigenous peoples.

\section{Conflict of interests}

The authors declare that this article was carried out in the absence of commercial or financial relationships that could be interpreted as a possible conflict of interest.

\section{Expressions of gratitude}

The authors wish to thank the reviewers for their valuable comments, aimed at improving the communication, efficacy, and overall quality of this manuscript.

\section{References}

1. CEPAL. El impacto del COVID-19 en los pueblos indígenas de América Latina-Abya Yala: entre la invisibilización y la resistencia colectiva. Comisión Económica para América Latina y el Caribe. 2020:87.

2. Dios M de. Impacto y situación de indígenas ante el Covid-19: Por. Python Cookbook. 2013;1989:706.

3. Department Economic, Social Affairs. Pueblos indigenas y la pandemia del COVID-19: consideraciones. Departmente of Economic and social affairs. 2020.

4. Meneses-Navarro S, Freyermuth-Enciso MG, Pelcastre-Villafuerte BE, Campos-Navarro R, Meléndez-Navarro DM, Gómez-Flores-Ramos L. The challenges facing indigenous communities in Latin America as they confront the COVID-19 pandemic. International Journal for Equity in Health. 2020;19:250-1. doi:10.1186/s12939-020-01178-4.

5. Kersffeld D. El coronavirus y la geopolítica del miedo. Seguridad, salud y racismo. Pensamiento propio. 2020:17-44.

6. Equipo de derechos y comunidades WCS. La pandemia COVID-19 y los pueblos indígenas y comunidades locales : protegiendo personas, protegiendo derechos. Equipo de derechos y comunidades. 2020.

7. Escola de Cultura de Pau. Altos el fuego en conflictos armados durante la pandemia del coronavirus. Apuntes ECP de Conflictes i Pau. 2020:1-5.

8. International Committee of the Red Cross. El dih en tiempos de covid-19. International Committee of the Red Cross. 2020:19.

9. Oficina de Naciones Unidas para la Coordinación de Asuntos Humanitarios. Pueblos indígenas y COVID-19 en América Latina: Un enfoque humanitario. Oficina de Naciones Unidas para la Coordinación de Asuntos Humanitarios. 2020:1-27.

10. Chandrasekaran B, Fernandes S. Since January 2020 Elsevier has created a COVID-19 resource centre with free information in English and Mandarin on the novel coronavirus . The COVID-19 resource centre 
is hosted on Elsevier Connect, the company' $\mathrm{s}$ public news and information website. Diabetes Metab Syndr. 2020;14(4):337-9.

11. Organizacion de las Naciones Unidas. Guia: Covid-19 Y Los Derechos De Los Pueblos Indígenas ¿Cuál Es El Impacto Del Covid-19 En Los Derechos De Los Pueblos Indígenas? Organizacion de las Naciones Unidas. 2020:114.

12. Beijer S, Bunting H, Campbell AG, Caron JK, Chernova A, Chin S, et al. El conflicto en tiempos del coronavirus. Oxfam Internacional. 2020:28. doi:10.21201/2020.6058.

13. Nick H. Efectos de la COVID-19 en las comunidades indígenas: Una mirada desde el Navegador Indígena. Navegador indigena. 2020:1-52.

14. Organizacion de las Naciones Unidas. Informe de política ONU / DESA \# 70: El impacto de COVID-19 en los pueblos indígenas. Organizacion de las Naciones Unidas. 2015:17.

15. Banco Interamericano de Desarrollo. ¿Cómo afrontamos la crisis del COVID-19? Consideraciones para organizaciones y comunidades indígenas para responder al COVID-19. Banco Interamericano de Desarrollo. 2020:1-14.

16. Organizacion Panamericana de Salud. Consideraciones relativas a los pueblos indígenas, afrodescendientes y otros grupos étnicos durante la pandemia de la COVID-19. Organización Panamericana de la Salud. 2020:15.

17. Oxfam. Evitar el Etnocidio: Pueblos indígenas y derechos territoriales en crisis frente a la COVID-19 en América Latina. Oxfam. 2020:21. doi:10.21201/2020.6294.

18. El Comercio. Casos de contagio por covid-19Ecuador finaliza el año 2020 con 212512 casos de contagio por covid-19. ComercioEcuador. 2020.

19. Instituto Nacional de Pueblos indigenas. Guía para la atención de pueblos y comunidades indígenas y afromexicanas ante la emergencia sanitaria generada por el virus sars-cov2 (covid-19). Instituto Nacional de Pueblos indigenas. 2020;2.

20. Leal J, Daniel P. El covid-19 y el derecho a la información de los pueblos indígenas en la región de Arica y Parinacota. SIT Collections. 2020.

21. Dal Poz J. Covid-19, transmissão comunitária e óbitos: como a pandemia chegou aos CintasLargas, em Mato Grosso e Rondônia. Aba Antropologia. 2020;4:57-71. 